\title{
Possible Sustainability of Intermodal Transportation in Africa
}

\author{
Che Kingsley Chenikwi ${ }^{1}{ }^{\circledR}$, Xuefeng Wang $^{2}$ \\ ${ }^{1}$ Institute of Scientific Research, Shanghai Maritime University, Shanghai, China \\ ${ }^{2}$ College of Logistics Engineering, Shanghai Maritime University, Shanghai, China \\ Email: kingsleyche01@gmail.com,wangxf@shmtu.edu.cn
}

How to cite this paper: Chenikwi, C.K and Wang, X.F. (2019) Possible Sustainability of Intermodal Transportation in Africa. Open Journal of Applied Sciences, 9, 139-158.

https://doi.org/10.4236/ojapps.2019.94013

Received: March 11, 2019

Accepted: April 9, 2019

Published: April 12, 2019

Copyright $\odot 2019$ by author(s) and Scientific Research Publishing Inc. This work is licensed under the Creative Commons Attribution International License (CC BY 4.0).

http://creativecommons.org/licenses/by/4.0/

\begin{abstract}
The lack of adequate and modern transport infrastructures makes the cost of transport in Africa higher than the rest of the world. Most of the transport infrastructures that exist were constructed during the colonial era which makes inter-regional connectivity difficult. The African Union in collaboration with other organization has committed to bridge the transport gap in Africa but still, face some challenges. This paper discusses the main issues that contribute for the weak nature of transportation in Sub-Saharan Africa with regards to the main transport modes and seeks to establish the possibility of sustainable intermodal transport through the integration of the different transport modes. Some policy reforms and other bilateral agreements such as deregulating the transport markets in West and Central Africa have been suggested to facilitate the development of an effective and efficient transport network in the Sub-Saharan African region.
\end{abstract}

\section{Keywords}

Intermodal Transport, Intermodal Integration, Network, Infrastructures, Corridors, Gateway Port

\section{Introduction}

There has been a high level of transformation through technology in the transport industry on a global scale. When we look at the transportation industry in the 80s, 90s and this new era of information and technology, it is interesting to experience how technology has transformed the transportation industry on a global scale. There is still much research that is being carried out to continue to improve the efficiency and effectiveness of this industry. More and more studies 
are carried out in the maritime, rail, road and air modes of transportation with little research being carried out on inland waterways and pipelines. To ensure an efficient transportation practice, the use of multimodal transportation is necessary. Multimodal transportation requires the usage of more than one transport mode to move passengers and freight from one point to another. Combining two or three modes of transport is essential for the smooth transportation of goods. The different intermodal combinations could either be road-rail, roadmaritime, road-air and many other combinations that could be applied. Various concepts are now in use when more than one mode of transport is used to transport goods. All these concepts are now practised throughout the world especially in North and South America, Europe and part of Asia. However, only some few countries in Africa practice these concepts efficiently and effectively. The most utilised mode of transport in Africa is the road transport mode, followed by air, maritime and rail respectively. The inland waterways and pipelines are not often put into use. Most of the transport infrastructures in several African countries date back to the era of colonisation.

The colonial authorities which were France, Germany, England and Portugal believed that investing in transport infrastructures had a positive relationship with economic development [1]. A significant level of investment in transportation during the colonial era was mainly on railways and seaports because these modes were vital for the exportation of natural resources overseas and also for military purposes [2]. Since the mid-1980s, there have been revelations that investments in public infrastructure contributed to economic development in industrialised countries. There is a direct relationship between a country's economic developments with the development of its public infrastructures. One of the most important reasons that a country such as China could develop very quickly was because of massive investments in its transportation sector with regards to its seaports, airports, roads, railways and inland waterways to support the manufacturing industries and this paved the way for fast and sustainable economic development. The same is true for European countries and the US. Their continuous investments in modern and sustainable transportation infrastructures help them achieve their high levels of economic developments.

Most transport infrastructures in Sub-Saharan Africa as earlier mentioned dates back to the colonial era. The reason is that most governments have not put in enough effort to improve these infrastructures due to poor political and economic conditions. Hence, the lack of interregional links makes transportation difficult [3]. Another reason for the weak states of these infrastructures is due to difficult geographical conditions such as high level of rainfall, mountainous landscapes, valleys and rivers. Apart from the problem of inadequate and ill-maintained transport infrastructure, the continent is saddled with institutional hurdles, including but not limited to, costly, antiquated and cumbersome administrative and customs procedures, corrupt officials and staff, and a litany of other deficiencies [1]. 
On the bright side, most African countries have begun investing in their various transport infrastructures. These investments have led to a high level of competition among African ports. Many port expansion projects are being carried out and also a lot of new constructions on multipurpose terminals. Also, there is a high level of investments carried out in international airports, but little on national airports. Meanwhile, the level of investment in road networks and railway lines have also increased especially in East Africa. Table 1 shows some of the transport infrastructure projects that have been carried out in Sub-Saharan Africa.

It is vital for African governments to be aware of the fact that there can be an improvement in the productivity of human and physical capital through the availability of infrastructures. The growth in productivity will reduce the cost of production and logistics which will translate into a high demand for the region's goods and services. Also, when infrastructure itself is considered a direct factor input, it attracts a higher level of investment which results in the higher regional output. Transportation has a significant implication for globalisation, and this is one of the primary reasons why many emerging economies do not do so well on global economic systems [4]. The reason for this poor economic performance is partly because these economies do not link to the arteries of international trade (i.e. roads, rails, sea and airports) that moves the world's economies, and promote growth and this is the problem that most African countries face. Because of the lack of intermodal integration, the transportation cost in most African countries, especially in the land lock countries, is significantly high. The high transport cost is the reason for the high price of African products and their inability to compete in international markets [4].

Table 1. Some transport infrastructure projects in Sub-Saharan Africa.

\begin{tabular}{lcc}
\hline \multicolumn{1}{c}{ Infrastructure projects } & Region & Source \\
\hline$>$ & The Awash Woldia/Hara Gebeya railway project. & Ethiopia \\
$>$ The Grand Trans East African Railway. & East Africa & Infra East Africa \\
$>$ LAMU Port and South Sudan-Ethiopia Transport Corridor & Kenya-Uganda & Africanews.com \\
$>$ Mombasa-Nairobi-Kampala rail project & Nigeria & Sub-Saharan Africa \\
$>$ A newly constructed railway line linking Abuja-Kaduna & Sub-Saharan Africa & Constructionreviewonline.com \\
$>$ Cairo-Cape Town highway project & Namibia & Mozambique \\
$>$ Construction of Walvis Bay Port new container terminal. & Cameroon & South Africa \\
$>$ The Maputo-Katembe Bridge Africa's longest suspension bridge & Angola & Tanzania \\
$>$ Construction of Yaoundé-Douala expressway. & & Chinadaily.com.cn
\end{tabular}




\section{Developing an Intermodal Integration}

\subsection{Global Intermodal Integration}

Global integration of the different modes of transport is essential for the sustainability of the world's economies. Most of the challenges that face modal integration on a worldwide scale are because most countries used to focus on passenger transportation rather than on freight transportation. When it comes to urban freight transportation, there are still some significant difficulties due to the lack of sufficient planning approaches [5]. Some cities still find it challenging to recognise solutions that can help in the urban transportation of freight [6]. The European Commission understood this challenge and assisted in the development of a Sustainable Urban Transport Plan (SUTP) as an integrated approach to help solve this problem [7]. In recent years, the integration of intermodal transportation is rapidly improving, and this is possible due to government policies, modern transportation infrastructure technologies and also information and communication technologies. The Staggers Rail Act of 1980 that deregulated the railway Sector in the US [8] is an example of how policies can transform the transport sector. Due to increased flexibility and economic freedom freight railways were able to design services more to customer needs, quote market-based freight rates and deal with their infrastructure as required. As a result, the total volume measured in revenue ton/miles doubled in the postStaggers era [8]. The deregulation also led to the construction of the land bridge that connected the west coast to the east coast of North America. This land bridge played a significant role in the integration of intermodal freight transport by reducing transportation time significantly. A container that was shipped to New York via Panama Canal from Singapore toke 36 days meanwhile it takes 19days by using the landbridge. The Landbridge also competed for market share traffic between Asia and Europe. The average shipping time from the ports of Rotterdam to Tokyo was 5 to 6 weeks, but it took about three weeks when the freight was transshippedthrough the North American landbridge with the transhipment taking 3.8 days [8]. Figure 1 shows the different landbridges linking the East coast to the West coast of North America. A land bridge is a combination of two modes of transportation being maritime transport and land transport (mostly rail) as an alternative to using just maritime transport mode. The land bridge does not only reduce time but also help reduce shipping cost by operating a double-stack container train service. The European Union also released a policy on combined transport that also changed the scope of transportation in the E.U [9]. The paper discusses the integration of different transport modes, and this gives an overview of intermodal integration.

It is no doubt an exciting fact that establishing a land bridge is one of the best ways to ensure intermodal integration that will reduce shipping distance and efficient distribution of freight. Another major land bridge is the Eurasian landbridge that covers the EU and the Eastern part of Asia which is also in line with China's one road, one belt initiative. One of the Eurasian block trains is the 


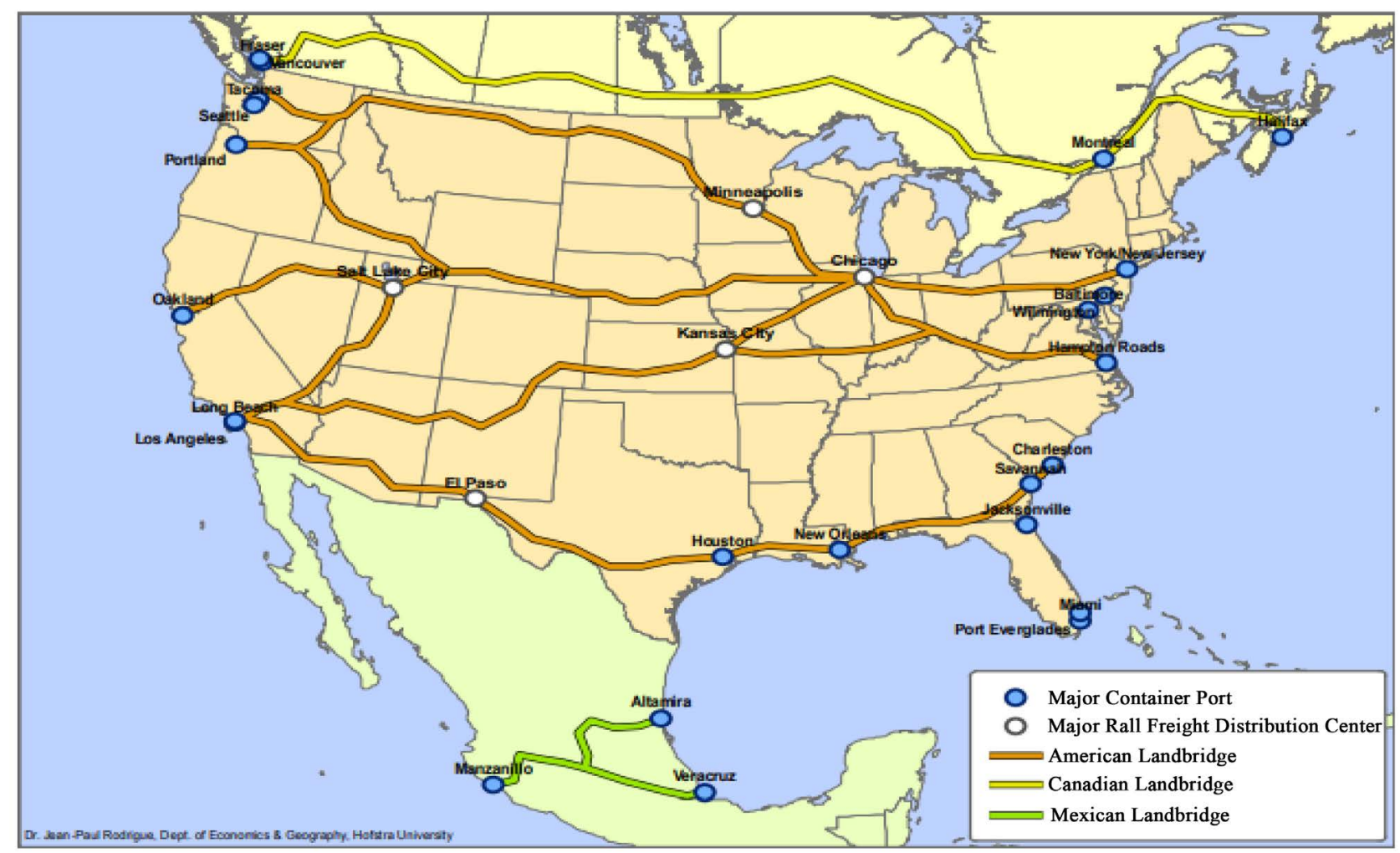

Figure 1. Landbridge links in North America Source: Jean-Paul Rodrigue (Intermodal transportation and integrated transport systems).

Chongqing-Duisburg block train that goes through China, Kazakhstan, Russia, Belarus, Poland and Germany as shown in Figure 2. Even though China and Europe stillcarry out a large percentage of their trade through maritime transport, there is a high possibility that the Eurasian land bridge will experience a high level of growth in the future. The construction of this land bridge has helped reduced shipping time from China to Europe. For example, it takes 36 days to ship a container from Chongqing (China) to Duisburg (Germany) through maritime and only 16 days through the land bridge [31]. There has been a total of 35 Chinese cities that have been linked to 34 European cities through the Eurasian land bridge by 2018. Table 2 demonstrates different cities in china that are connected to some European cities through the Eurasian land bridge. This Eurasian land bridge is in connection with the one road one belt vision of China to reach more international markets.

Some of the significant land bridges in the world include the following;

- The North American land bridge which links the west coast (Long Beach \& Los Angeles ports) and the east coast (New Jersey \& New York ports).

- The Canadian land bridge which links Halifax on the west coast to Vancouver to the West.

- The Mexican land bridge which links the port of Salina Cruz located on the Pacific Ocean and the port of Coatzacoalcos situated on the Gulf of Mexico.

- The Siberian land bridge is linking Japan, Korea and Europe. 


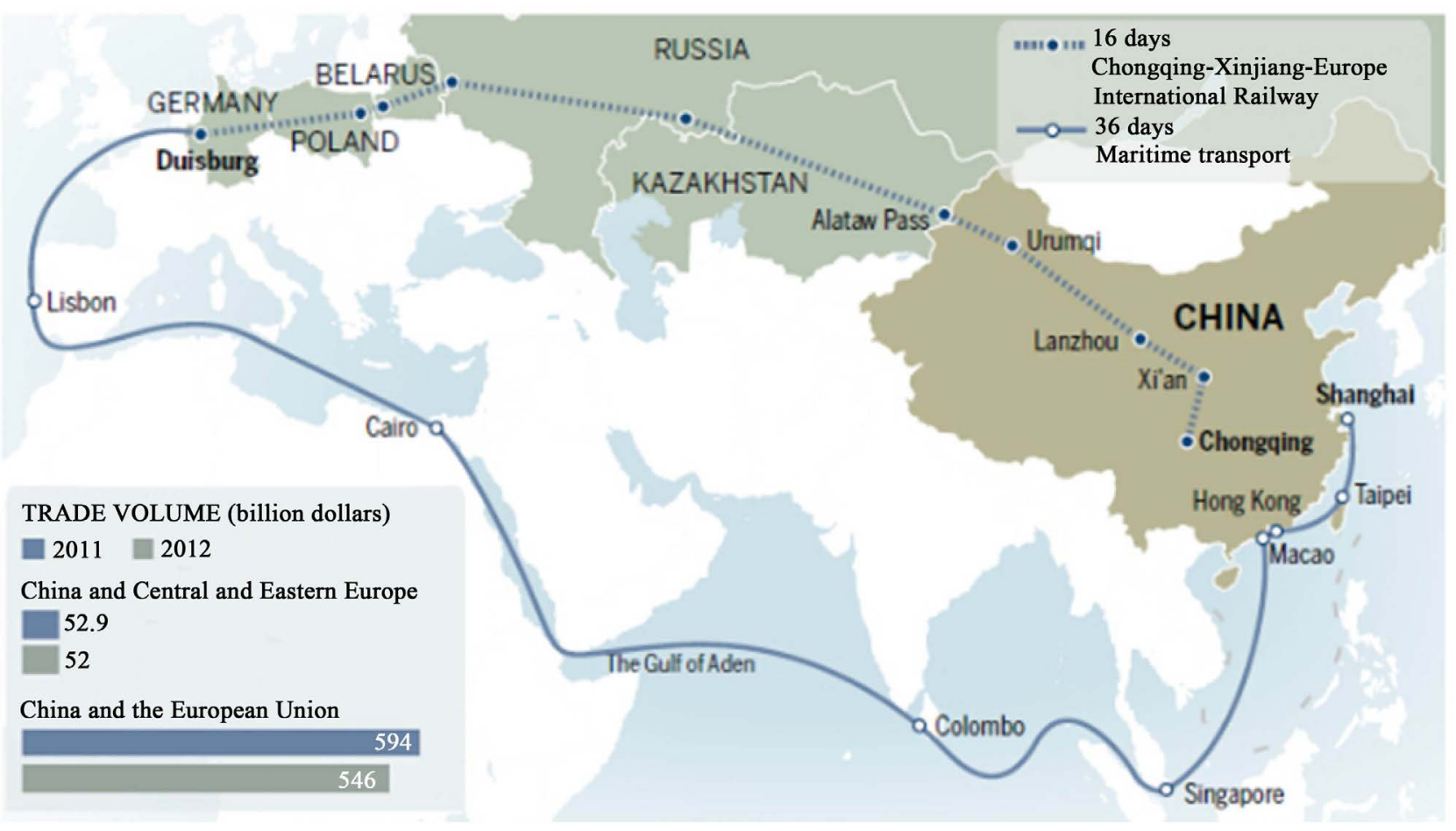

Figure 2. A faster route for trade between Chongqing and Duisburg Source:

(https://voxeu.org/article/eurasian-landbridge-linking-regional-value-chains).

Table 2. Chinese cities connected to European cities by rail.

\begin{tabular}{ccc}
\hline Route & Length $(\mathrm{km})$ & Duration (days) \\
\hline Chongqing-Duisburg & 11,1791 & 16 \\
Wuhan-Mēlnik & 10,863 & 16 \\
Suzhou-Warsaw & 11,200 & 18 \\
Chengdu-Łódź & 9826 & 10.5 \\
Zhengzhou-Hamburg & 10,124 & $19-20$ \\
Yiwu-Madrid & 13,052 & 21 \\
Hefei-Kazakhstan; Hefei-Hamburg & $c 11,000$ & 15 \\
Changsha-Duisburg/Moscow/Tashkent & 11,808 & 18 \\
Habin-Hamburg & 9820 & 15 \\
Wuhan-Lyon & $\ldots$ & 15 \\
Yiwu-London & $\ldots$ & $\ldots$ \\
\hline
\end{tabular}

Source: VOX CEPR Policy Portal.

- The Eurasian land bridge linking China to Europe.

- The Malaysia-Thailand land bridge linking the Klang port to Bangkok [10].

As earlier mentioned, the primary approach used in the integration of two or more transportation modes is through combined transport (CT). There are different definitions for combined transport, but for this paper, combined transport will be defined as "the transportation of freight using two or more modes of 
transportation from the point of origin to the point of destination." Two types of combined transport will be considered which are Maritime CT and Continental CTas shown in Figure 3. The maritime CT will refer to the transportation of freight between seaports and inland terminal, and the continental transport will apply to the transportation of cargo between inland terminals. The cargo is usually carried out by combined transport companies. The maritime CT can be sub-divided into sea/road, sea/rail, inland waterway/road and inland waterway/rail, short-sea/inland waterway/road, inland waterway/rail/road.

In the EU, international CT accounts for the highest market segment of all CT operations. It accounts for $51.5 \%$ of the total TEU and tones transported [9]. When considering the road/rail CT, freight moved at the distance of $100 \mathrm{~km}$ or less is not negligible. It is because of intense competition by road haulage when cost and transit time is a consideration. Although the road/rail CT can benefit from economies of scale, they can be affected by extra handling cost. A comparison of the road/rail CT between the EU and North America (Mexico, Canada, US) is demonstrated in Table 3. With the inland waterway/road CT, it is possible for freight to be transported within a distance of $100 \mathrm{~km}$. The inland waterway/ rail/road CT is often used where the barge capacity is higher than the train capacity and also where the high capacity of the barge can compensate for the extra handling charges.

From Table 3 North American demonstrates a high density of road traffic as oppose to the EU and also North America has a high tonnage of freight transported by rail with a modal share of $41 \%$ of road/rail while EU has a modal share of $22 \% \mathrm{road} / \mathrm{rail}$. But the EU has a relatively higher rail network size when compared to the rail network size of North America. Despite the larger size of the EU rail network size, it has a lesser average haul length when compared with the average haul length of the rail network size of North America.

Table 3. Comparing EU and North America.

\begin{tabular}{cccc}
\hline Indicator & Unit & North America & EU \\
Area & million km $\mathrm{km}^{2}$ & 22 & 4.3 \\
Population & Million & 467 & 504 \\
Population density & people per km ${ }^{2}$ & 21 & 117 \\
Gross Domestic Product & \$ trillion & 18.1 & 239 \\
Rail network size & thousand km & 223 & 419 \\
Rail freight traffic & bn tone-km pa & 2501 & 1519 \\
Road freight traffic & bn tone-km pa & 3626 & $22 \%$ \\
Rail mode share (of total road/rail) & \% total tone-km & $41 \%$ & 375 \\
Rail freight average length of haul & Km & 1475 & 510 \\
Rail freight average train payload & Tones & 3209 & 17.2 \\
Intermodal units moved by rail & million TEU & 28.7 & 390 \\
Rail passengers & bn passenger-km pa & 12.8 & \\
\hline
\end{tabular}

Source: Intermodal Association of North America, Kombi Consult calculations. 


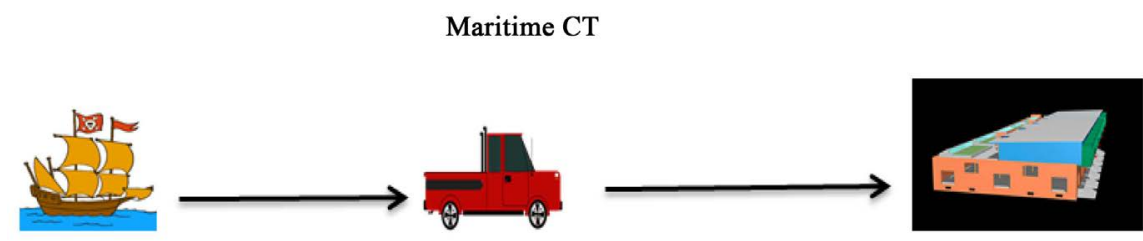

Continental CT

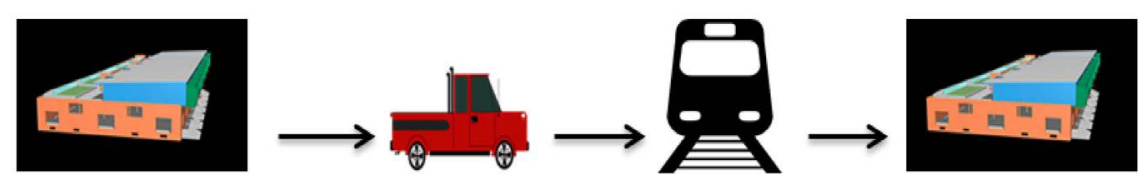

Figure 3. Different types of CT (Author's illustration).

Integrating rail and inland waterway transportation within an intermodal chain is very important for CT service competitiveness. Coordinating road and rail can always be improved. CT services facilitate the growth of the supply chain especially with regards to door-to-door services. It means that CT operators have to provide alternative means of transport to satisfy customers in cases of service interruption. One other important aspect that can enhance the CT services is the establishment of hinterland hubs, especially for the inland waterway. If hinterland hubs are developed for inland waterway for container transport to serve as extended gateways, this will help to improve the inland waterway/road CT services. It will improve on the consolidation of freight and also reduce cost. Hubs that serve as extended gateways will complement facilities for maritime container transport. These services will help in relocating container storage at these a port terminal to the hinterland hubs through effective and efficient barge links. It can also be helpful when the container traffic volume exceeds the capacity of the seaport.

Apart from the obvious reasons that CT will facilitate the movement of goods, more emphases are on CT transport because of environmental considerations. About $95 \%$ of the world's vehicles use fossil fuel which is one of the leading causes of the high level of carbon dioxide $\left(\mathrm{CO}_{2}\right)$. The high emission of $\mathrm{CO}_{2}$ is believed to be the number one cause of global warming. However different options are being deployed in various countries such as the use of electric and solar systems to power vehicles and other methods are being researched such as the use of hydrogen to power vehicles. Until sustainable practices can be developed and utilised on a large scale, fossil fuel will remain the primary source of energy. It shows the importance of using CT especially road/rail, road/inland waterway to minimise the level of $\mathrm{CO}_{2}$ emissions.

\subsection{Integration of Key Nodes into the Intermodal Network}

Intermodal networks cannot fully function without the integration of key nodes within the transportation network. The keys nodes that ensure the smooth operation of every intermodal network are the seaport and the inland terminals or 
the dry port. There is a proliferation of the number of containers handled by ports especially those in a good geographical location which has led to an increase in intermodal connectivity [11] and [12] proposed that terminal operators should implement strategic planning to facilitate intermodal transportation. Much research has been carried out on different strategic models to optimise transportation, but little has been done on business models to facilitate the growth of intermodal transport [13]. Transportation networks can be developed into different distribution systems as demonstrated in Figure 4. These systems have played a major role in the integration of intermodal networks. These network systems could be a point-to-point system which entails transporting freight from one point (origin) to another point (destination) without transhipment [14]. There is also the corridor system which uses services such as the land bridge to ensure efficient distribution of freight. Another network system is the hub and spoke system that provides an extensive configuration of fright distribution.

Most intermodal networks serving the hinterlands operate within a transport corridor. A transport corridor is a combination of two or more transportation modes or a single transportation mode that links two or more nodes together. Most often transport corridors start from a key node. Sometimes these key nodes could serve as hub ports or gateway ports from country A to landlocked country $\mathrm{B}$ or $\mathrm{C}$ as illustrated in Figure 5. A gateway can is defined as an interface that links different facilities in a transportation network to enhance freight distribution to different hinterland locations and landlock countries through a corridor. Most ports are considered as gateway ports because they have a good geographical location and a good transportation network system with facilities like inland
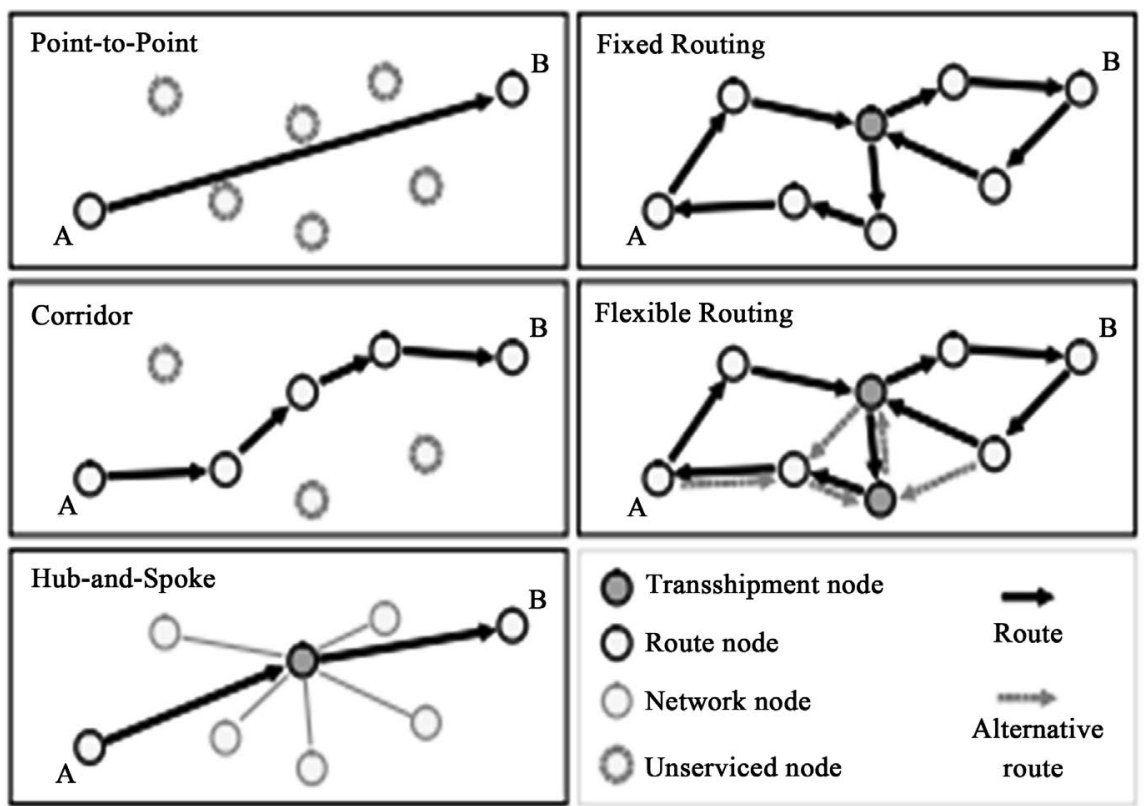

Figure 4. Freight distribution systems Source: The transport geography of logistics and freight distribution. 


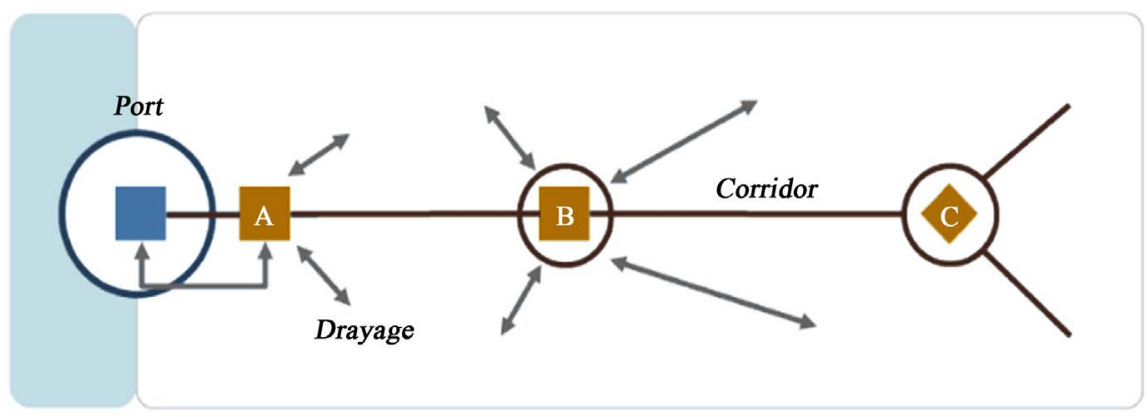

Figure 5. An illustration of a gateway concept source: Jean-Paul Rodrique (Port terminals).

terminals, warehouses, distributions Centre, customs, finance institutions that can facilitate the distribution of freight to the hinterland and landlocked countries. A gateway is mostly the primary point through which goods go into or out of a country or a region. The evolution of intermodal transport has re-enforced the functions of gateway ports as they provide transhipment services thereby improving on the efficiency of the shipment of freight from their point of origin to their destination points [8]. Most gateway points are located along major transportation corridors, and they sometimes function as hubs in the case of port terminals. However, the difference between a gateway and a hub is that gateways connect different transport modes, but a hub is a central location connecting inflows and outflows of freight using the same transport mode. Proper coordination of the gateway ports and the transport corridors requires all the actors to be willing to invest and carry out strategic planning to make it work [15].

Gateways can be divided into three categories which are the land gateway, maritime gateway and the air gateway. The land gateway mostly serves as a transhipment point linking the different logistics functions together to ensure smooth distribution of freight. Maritime gateways are made up of large terminals that are highly connected to the roads and rail networks, and finally, the Air gateways connect with different cities or regions either by air or by road, and they have a high level of inland location and connectivity. The concept of gateways is to extern the delivery of freight to the shipper from the port terminals to the hinterlands through a transport corridor to an inland terminal or dry port [16]. Figure 6 demonstrates the major gateways in North America.

\section{Transportation in Africa}

\subsection{Establishing an Efficient Intermodal Integration in Africa}

It is important to determine the reasons behind the inefficient and ineffective integration of intermodal transport in most African countries. It is impossible to implement intermodal integration without good supportive infrastructure, most importantly roads [17]. Most African countries transport infrastructures are not really in a good state. Most of these infrastructures constructed in the '70s, have 


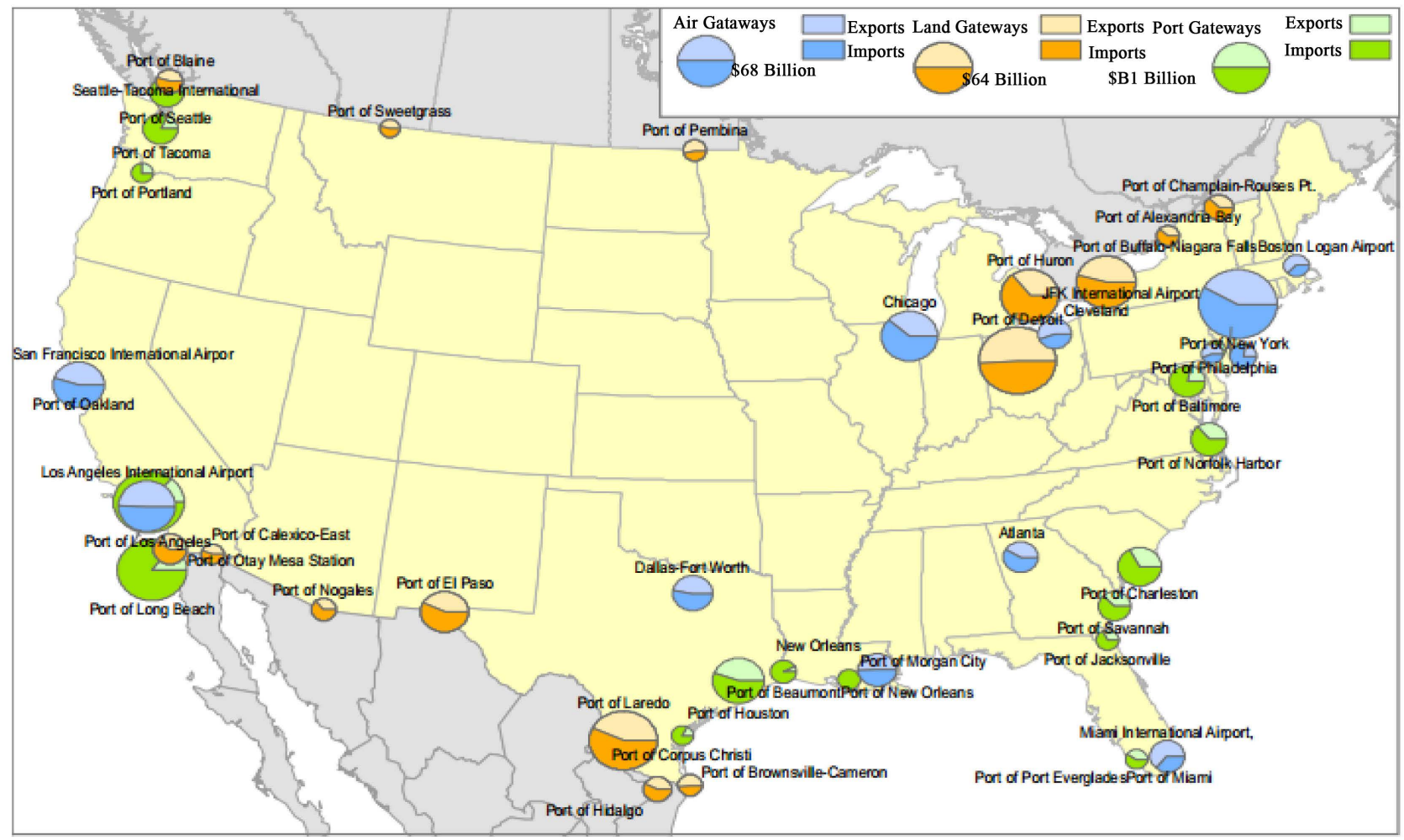

Figure 6. Major US gateways source: jean-paul. $\mathrm{r}$ (intermodal transportation and integrated transport systems).

little or no maintenance carried out. Sub-Saharan Africa has very few road networks having only about 204 kilometres of road per $1000 \mathrm{~km}$ of an area of land [18]. Improving the transport infrastructures in Africa will bring about the potential growth of the continent and will improve on the connectivity to the local and international markets and in agriculture [19]. There is, therefore, a high need to improve on Africa's connectivity as this is very important for development, and that is why the World Bank and other financial organizations with the African governments continue to put in more support in sustainable infrastructures than other sectors such as healthcare, education and social affairs [20]. In 2013, the World Bank invested about $\$ 15$ Billion in rural \& interurban roads [21].

The cost of transportation in African countries is relatively high; meanwhile, the transport services provided by the transport operators are not the best which could be attributed to the poor infrastructures. Logistics performance is not the best because of corruption mal-practices, inefficient truck or rail services, and a certain level of restriction of entry into the industry by modern operators [22]. There is a significantly low rate of vehicle utilisation and a high rate of old vehicle fleet (trucks or trains). Most of the transport corridors experience a high level of delays at the borders because of lengthy border crossing clearance formalities. There exist poor and unsustainable policies and bilateral agreements to support inter-regional transport integration by the state authorities of the different regions. There is a low transport network connectivity within the Sub- 
Saharan African regions. There is a high degree of poor transport safety and security with an inefficient transport information and communication systems. These are some of the reasons that prevent the synchronisation and integrations of intermodal transport from ensuring smooth distribution of goods. Most transport operators do not invest in new transport vehicles but rather go for second-hand trucks (already used vehicles) from abroad and add them to their already existing old fleet which renders freight transportation inefficient. These second-hand trucks have a higher rate of break down due to the poor nature of infrastructures, and less maintenance is carried out on them as well. In the West and Central Africa, the transport market is highly regulated serving as a ground for corruption for operators who want to acquire a huge market share. Most of these operators provide a low service quality at a high price mainly because they care about making profits rather than customer satisfaction. These operators complain of very high importation tariffs on new trucks hence the reason for the second-handed trucks. East and South Africa have a relatively low deregulated market with a higher level of competition which make the cost of transport relatively lower and a higher service level. Deregulating the transport market is essential for a fair competition which will bring higher service levels at a much lower transportation price. Table 4 shows some countries that deregulated their transport market and the impact it had on the market.

The nature of the roads in most countries will not permit modal integration. Most of the major roads are in dangerous conditions with many potholes especially in the rainy seasons because of heavy rains and sometimes because of truck overload which helps to damage the roads. Some are untarred, and it becomes very slippery when it rains. It increases the rate of truck breakdown hence a high

Table 4. Transport service deregulation in some countries.

\begin{tabular}{|c|c|c|}
\hline Country & Outcome of deregulation & Period \\
\hline France & $\begin{array}{l}\text { There was a significant reduction in the price of transportation } \\
\text { from } 40 \% \text { to } 10 \% \text { within a period of } 10 \text { years. }\end{array}$ & The deregulation was made in 1986 \\
\hline $\begin{array}{l}\text { Poland, } \\
\text { Czech Republic, } \\
\text { Hungary }\end{array}$ & $\begin{array}{l}\text { It caused an increase in the number of new entrants which } \\
\text { caused innovation in logistics services provided and also are } \\
\text { duction in transport prices. The first transport sector to be } \\
\text { liberalised or privatised was freight road transport. }\end{array}$ & The policy was passed between $1990-1998$ \\
\hline Mexico & $\begin{array}{l}\text { More transport operators joined the market, and it improved } \\
\text { trucking services increasing access, speed and frequency of } \\
\text { delivery. The deregulation period was gradual for two years }\end{array}$ & The policy was adopted in 1989 \\
\hline Indonesia & $\begin{array}{l}\text { A new entrance into the market and transport price set by } \\
\text { the market will lead to a reduction in transport pricing. } \\
\text { Trucks need licenses to cross borders. }\end{array}$ & The deregulation was carried out in 1985 \\
\hline Morocco & $\begin{array}{l}\text { There was the elimination of government freight allocation } \\
\text { monopoly which caused a dramatic drop in freight prices. }\end{array}$ & The freight allocation was abolished in 2003 \\
\hline Rwanda & $\begin{array}{l}\text { There was an increase in the number of local truck } \\
\text { operators that reduce the price of transport to about } 75 \% \text {. }\end{array}$ & $\begin{array}{l}\text { The policy was passed in } 1994 \\
\text { after the Rwanda genocide. }\end{array}$ \\
\hline
\end{tabular}

Source: Transport prices and cost in Africa: A review of the main international corridors. 
maintenance cost, and it also slows down the speed of the trucks which lead to high consumption of fuel. Research shows that in cases where the road conditions in Central and West Africa is improved, the cost of transport is still high while the same conditions in the East and South of Africa have instead let to a reduction in the cost of transportation [22]. In Sub-Saharan African, the cost of lubricant and fuel with the cost of tires dramatically contributes to the reasons of high transport costs in the region. Research has also shown that central Africa has the lowest Logistics Performance Index (LPI) followed by West, East and South Africa. It means that not only are the transport cost high but also, they offer a low-quality service which is a paradox. There is a Trans-African Highway project known as TAH that is being carried out to connect Northern, Western, Central, Eastern and Southern African countries. The network is expected to link 83 cities with a total length of about 100,000 km [23]. Once this project is executed, the missing links within the existing networks will be established which will lead to an efficient road network connectivity. It is a good step towards intermodal integration provided the rail networks are also developed. Apart from the TAH project, China has also invested heavily in infrastructures in Africa especially in the construction of new ports and other sectors especially counties rich in natural resources [17]. China has invested about \$13.9 billion in infrastructure projects in Africa between 2010 and 2013. By 2014 about $67 \%$ of total financial investment on Africa's infrastructure comes from China [24].

Through the means of combined transport, the road network can be integrated with the rail networks through a terminal that connects the two modes. From the gateway port, containers should be transported by railway to an inland terminal in the West or Central Africa and then transferred on trucks for distribution to the customers. The could also be the possibility to develop an inland hub that will receive a direct shipment of freight from the port of Mombasa and then redistribute them to the West and Central African countries by road transport to enable efficient integration of the two transport modes. With the rising concern of environmental protection, using the railway as a land bridge between the East and the West of Africa will be the best transport option as opposed to road transportation. Therefore, there is a high need for investment in a rail network in Sub-Saharan Africa. This rail network will be advantageous because it can cover a longer distance at a shorter time and also carry more containers with less fuel consumption [25] and a reduction in air pollution as transportation activities are some of the most significant contributors of air pollution [26]. However, according to Qu. Y et al;; (2014) [27], the use of intermodal transport with the aim of reducing air pollution instead of using road transport does not usually apply with the purpose of reducing environmental emission. Other aspects need to be considered as well such as the transport distance, the size of the vessel and also the source of electricity for the electric trains. Table 5 gives a range of emissions from different port operations and different transport modes. If the rail network is well developed, it could be employed as a shuttle which runs twice 
Table 5. Different emission range from port operations and transport modes.

\begin{tabular}{|c|c|c|}
\hline Emission area & $\begin{array}{l}\text { Range of } \\
\text { emission }\end{array}$ & $\begin{array}{l}\text { Significant factors of } \\
\text { emission per freight }\end{array}$ \\
\hline \multicolumn{3}{|l|}{ Transport mode (gram $\mathrm{CO}_{2}$ per ton $/ \mathrm{km}$ ) } \\
\hline Road & $60-140$ & $\begin{array}{l}\text { Load rate, weight/volume ratio, } \\
\text { quality of truck, } \\
\text { traffic conditions, truck speed }\end{array}$ \\
\hline Rail & $20-50$ & $\begin{array}{l}\text { Load rate, train size, power system } \\
\text { (electricity or diesel), } \\
\text { the speed of the train. }\end{array}$ \\
\hline Deep Sea shipping & $7-10$ & Vessel size, utilisation, speed \\
\hline Short Sea shipping & $15-30$ & Vessel size, utilisation, speed \\
\hline Small RoRo & $50-60$ & Vessel size, utilization, speed \\
\hline Barge & $20-50$ & $\begin{array}{l}\text { Vessel size, the speed of water } \\
\text { (on the river), utilisation rate, speed }\end{array}$ \\
\hline Bulk shipping (large vessels) & $5-7$ & Vessel speed and size \\
\hline Air freight (medium to long haul) & $50-800$ & Size of aircraft, distance, utilisation \\
\hline Pipeline & $4-6$ & Barge size \\
\hline \multicolumn{3}{|l|}{ Transport node (kg per TEU or ton) } \\
\hline Handling of a container in a seaport & $\begin{array}{l}12-20 \\
(\mathrm{TEU})\end{array}$ & $\begin{array}{l}\text { Terminal size and equipment, } \\
\text { number of intra-terminal moves }\end{array}$ \\
\hline $\begin{array}{c}\text { Handling of a container at an inland } \\
\text { Terminal }\end{array}$ & $\begin{array}{l}5-10 \\
(\mathrm{TEU})\end{array}$ & $\begin{array}{l}\text { Terminal size and equipment, } \\
\text { number of intra-terminal moves }\end{array}$ \\
\hline $\begin{array}{l}\text { Nautical services (vessel traffic } \\
\text { management, towage, mooring) }\end{array}$ & $\begin{array}{l}<1 \mathrm{~kg} \\
\text { per ton }\end{array}$ & $\begin{array}{l}\text { Fuel and sustainability of } \\
\text { pilotage and inspection vessels }\end{array}$ \\
\hline
\end{tabular}

Source : Berg, van de, R. (2015).

a week and subsequently increased with an increase in demand for the service. The use of shuttles will be possible if a standard gauge and the same rail wagon is used across the different countries to ensure smooth operation without having to load and offload containers from one train to another when crossing borders because of varying rail standards [28].

\subsection{Major Transport Corridors in Africa}

As previously discussed, transport corridors are the significant links between a gateway port and the hinterland. Transport corridors are the most appropriate means for intermodal integration in any transportation network. Almost all intermodal integration in North America, Europe and Asia are carried out through their major transport corridors. To enhance the possibilities of Africa developing an effective and efficient intermodal integration, a significant level of investments on infrastructure and favourable policies need implementing on these corridors. Each corridor needs to invest in rail infrastructures because the corridors are mainly dominated by road transport mode. For this to work, there 
must be a mutually supported political, institutional economic and investment conditions [29] [30]. It is interesting to note that most of the governments of the West and Central African states have signed some conventions to promote inter-state multimodal transportation as demonstrated in Table 6. The establishment of such agreements is the starting point to ensure an intermodal integration in Africa.

The primary transport corridors in Sub-Saharan Africa include:

- The Douala-N'djamena corridor made up of rail-road transport modes (Cameroon and Chad), and the Pointe-Noire-Bangui-N'djamena corridor made up of rail-river-road transport modes (the Congo Republic, Central African Republic and Chad). These corridors are located in central Africa.

- The West African corridor links Abidjan, Tema, Lomé, Cotonou the major gateway ports to the landlocked countries of Burkina-Faso, Mali and Niger.

- The Northern corridor located in East Africa links the port of Mombasa (Kenya) to Democratic Republic of Congo, Burundi, Uganda and Rwanda. The port of Mombasa is the largest port in East Africa.

- The North-South corridor links the Durban port (South Africa) to Zambia, Zimbabwe, DRC, Malawi and Tanzania. It is the most efficient corridor in Africa.

- The road networks that covers about $75 \%$ of all the transportation modes on all these corridors cannot support smooth freight transportation. Table 7 shows the conditions of some of the roads linking the major gateway ports to the hinterland/ landlocked countries.

Table 6. Bilateral agreement (conventions) in Sub-Saharan Africa. Source: UN Economic commission for Africa.

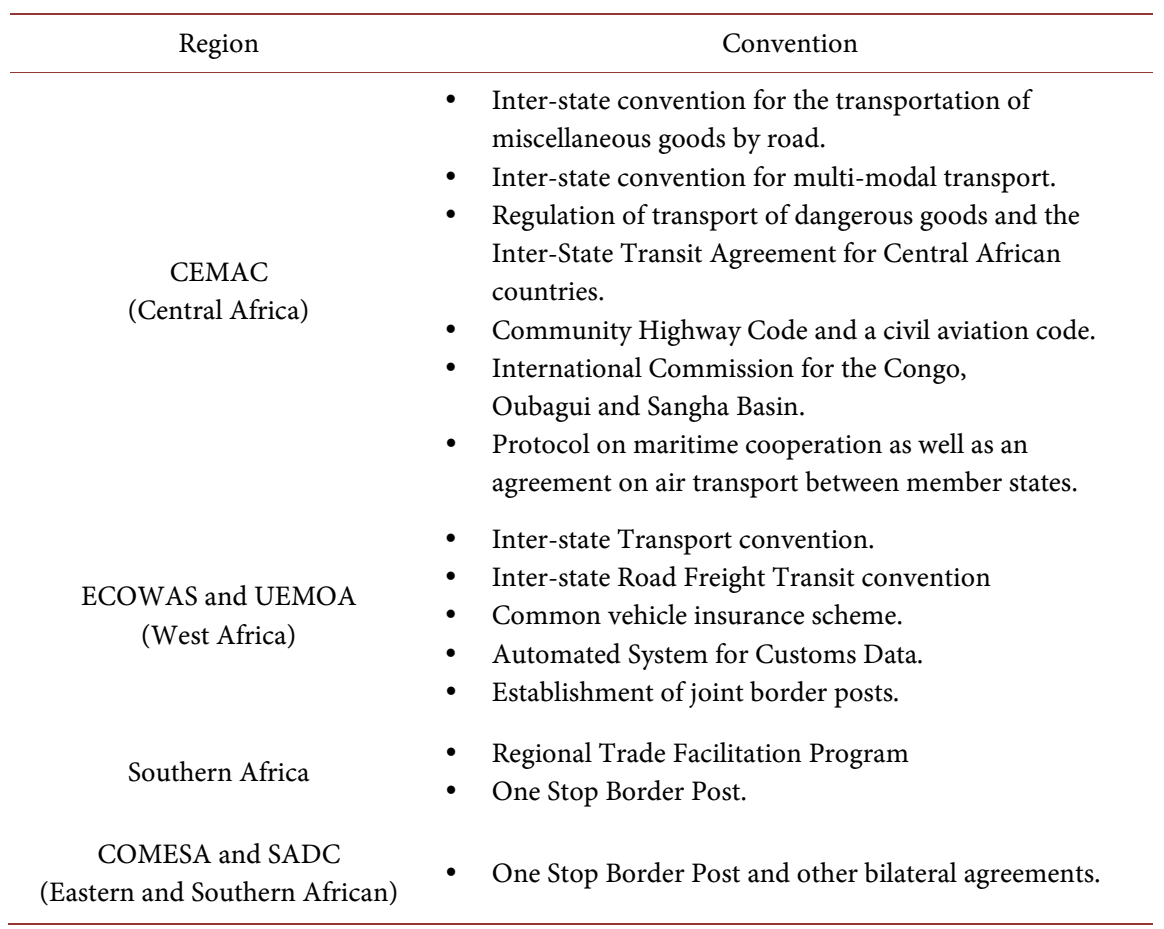


Table 7. Road conditions on major links.

\begin{tabular}{cccc}
\hline Corridor & Origin point & Destination point & $\begin{array}{c}\text { Percentage of the road } \\
\text { in the right conditions }\end{array}$ \\
\hline West Africa & Tema/Accra (Ghana) & $\begin{array}{c}\text { Ouagadougou } \\
\text { (Burkina-Faso) }\end{array}$ & 82 \\
Central Africa & Douala (Cameroon) & Namako (Mali) & 64 \\
& Nouala & Bangui (CAR) & 45 \\
& Ngaoundéré (Cameroon) & Moundou (Chad) & 53 \\
& Ngaoundéré & N'djamena & 100 \\
Northern corridor & Mombasa (Kenya) & Kampala (Uganda) & 61 \\
& Kampala & Kigali (Rwanda) & 75 \\
North-South & Lusaka (Zambia) & Johannesburg & 100 \\
\hline
\end{tabular}

Source: Supree, T (2009).

This paper has highlighted some of the major challenges faced by the transport industry in Sub-Saharan Africa. Despite all these shortcomings, the African continent has realized the importance modern transport infrastructures play in enhancing a sustainable international trade. The paper has discussed some of the practical steps and policies that some countries have put in place to promote intermodal transport such as the development of land bridge in North America and the Eurasian land bridge between China and the EU. Hence, this paper has sort to first discuss some of the main problem that affect intermodal transportation in most African countries such as bad roads, lack of appropriate maintenance of roads and railways tracks, lack of investment in this industry and seeks to provide some practical recommendations that can boost the potential of the transport industry.

The limitations to this paper concern other transport modes like inland waterways, pipeline and air transport. These modes of transports are under researched in Sub-Saharan Africa and more research needs to be carried out on these modes to ensure a sustainable intermodal transportation in Africa. Most African countries are involved in the extraction of natural resources like crude oil and providing pipeline for its transportation is important such as the pipeline project between Chad and Cameroon. Also, more research needs to be done on government policies that can attract foreign investment in this sector. There is a high potential for African countries to compete with the rest of the world in international trade if effective and efficient infrastructures are developed.

\section{Recommendations}

- Successful intermodal integration requires vehicles that are in functional status and hence the need for truck operators to import new or slightly used trucks. Governments should put a lump sum tax policy on all imported Lor- 
ries whether new or old. This policy will enable truck operators to import new trucks. Governments should also ban the importation of used vehicles that are eight years old and above. It will help improve the reliability of the trucks by reducing the level of maintenance carried out yearly due to truck break down and an increase in fuel consumption efficiency. This lump sum tax could help raise revenue for the government to reinvest in the construction or maintenance of roads. The government should also introduce an incentive for truck operators who employ newer trucks.

- The governments of the West and Central African countries should implement deregulation policies on the transport market. It will enable new entrants into the market, and this will help bring down the cost of transportation. Deregulation will also increase the trucking frequency leading to quick and frequent delivery times. Once the liberalisation is implemented such as aborting road controls with its associated tariffs, there is going to be a high level of competition because of the new entrants causing flexibility in transport prices from both rail and road operators and will help decrease the cost of transportation. It is sure that to implement a deregulation policy in the west, and central Africa would not be easy because some high-level government officials either own some of the trucking fleets or have some level of control in some trucking company and they can harm trade. Therefore, to successfully implement a deregulation policy, some compensation has to be paid to remedy the situation.

- There should be liberalisation of the transport market and let the market determine the transport prices. Liberalising the transport market means that transport operators should be issued an international license that will permit them to cross international borders to facilitate modal integration and to reduce delivery time especially across the boundaries of the west and central Africa. It will eliminate the loading and off-loading of goods across the border from one truck or rail to another hence removing pilferage and theft of goods and also eliminating delays in cross-border crossing. When the market sets the price of transport, there will be a friendly competition among the players which will cause an increase in the level of service provided.

- The government of countries along essential transport corridors should establish policies that would reduce border crossing delays. Most delays along significant corridors occur at the borders due to rigorous customs formalities. The best way to enable a successful intermodal integration is for different countries along a corridor to implement harmonised policies with the aim of reducing the import and export clearing procedures hence a reduction in border crossing time. A one-point check post could be established as custom checkpoint also to help minimise delay along a corridor. This point could have custom representatives of all the countries along a corridor that will ensure custom clearance formalities. Documents needed for customs clearance should be simplified, or there should be the implementation of electronic clearance system to help reduce the clearance time. It could also 
help reduce corruption along the corridors between customs officers and truckers.

- Most of the roads in Africa are very narrow. Significant high ways are just made up of two lanes which are highly insufficient to support efficient movement of trucks. It often leads to most congestion on the highways. Road expansions or rehabilitation to four or six lanes should be built to ensure efficient flow of vehicles and also reduce or eliminate road congestions.

- Policies implemented should capture agreements on arrangements on bilateral transportation across border and road tariffs or taxes should be harmonised. It should prevent different taxes at different borders to ensure a smooth modal integration, especially across borders. The governments should implement corridor management agency that manages the smooth operations of the corridors and to identify and implement punitive measures on mal-practices along these corridors.

- The railway sector in Africa is underdeveloped especially in the West and Central Africa. There is a tremendous investment opportunity for the private investor in this sector. If this sector is well developed like in Europe, the U.S and Asia, this will boost intermodal integration in these regions. African governments should create a lucrative investment environment and establish structured policies and reforms to attract private investors to help develop infrastructures to support the rail industry.

- There should be the implementation of highly effective ICT systems within the various transport networks to ensure an efficient transport operation through proper monitoring, and coordination of the different networks to provide a successful intermodal integration.

- Just like the trans-African road network project, a similar scheme should be established to develop infrastructure to link the African states through a railway network. New rail links should be constructed and connected with the existing railway lines.

\section{Conclusion}

Intermodal integration is essential for the development of the transport industry in African. It can only be achieved if the governments of the different African countries together with the African Union with help from other organisations like the UN, World Bank, African development bank put resources together to develop not only the road networks but also the rail networks. Most investments that have been carried out in recent years have mainly been on seaport and airports. As crucial as these nodes are, they cannot function at their optimum if the intermediary links being the road and the rail network are underdeveloped. Good policies also need to be established with bilateral agreements between countries along important transport corridors to help in ensuring quality services by transport operators along these corridors. America, Europe and Asia are well developed because they saw the importance of transportation and they in- 
vested in the infrastructures needed to support this industry and African countries need to use these continents as a benchmark to develop it transport industry.

\section{Fund}

This paper is supported by the Development Research Center of Shanghai $\mathrm{Mu}$ nicipal People’s Government (No. 2016-YJ-E02).

\section{Conflicts of Interest}

The authors declare no conflicts of interest regarding the publication of this paper.

\section{References}

[1] Njoh, A.J. (2007) Implications of Africa's Transportation Systems for Development in the Era of Globalization.

[2] Njoh, A.J. (1999) Urban Planning, Housing and Spatial Structures in Sub-Saharan Africa: Nature, Impact and Development Implications of Exogenous Forces. Ashgate, Aldershot.

[3] Vesely, M. (2001) Public Transport in Africa: A Game of Russian Roulette. African Business, 265, 12-13.

[4] Slater, R.E. (2000) A New Transportation Policy Architecture for a New Century.

[5] Crainic, T.G., Nicoletta, R. and Giovanni, S. (2004) The-Day-Before Planning for Advanced Freight Transportation Systems in Congested Urban Areas.

[6] Laeticia, D. (2007) Good Transport in Large European Cities: Difficult to Organize, Difficult to Modernize.

[7] European Commission (2006) Sustainable Urban Transport Planning.

[8] Jean-Paul, R. (2006) Intermodal Transportation and Integrated Transport Systems: Space, Networks and Flow.

[9] Frankfurt am Main (2015) Analysis of the EU Combined Transport.

[10] Valauttam, A. (2007) The Development of Container Landbridge Train Services between Malaysia and Thailand.

[11] Notteboom, T.E. and Rodrigue, J.P. (2009) Inland Terminals, Regions and Supply Chains.

[12] Song, D.W. and Panayides, P.M. (2008) Global Supply Chain and Port/Terminal: Integration and Competitiveness. Maritime Policy \& Management, 35, 73-87. https://doi.org/10.1080/03088830701848953

[13] Eng-Larsson, F. and Kohn, C. (2012) Modal Shift for Greener Logistics the Shipper's Perspective. International Journal of Physical Distribution \& Logistics Management, 42, 36-59. https://doi.org/10.1108/09600031211202463

[14] Ali, R., Barra, A.F., Berg, C., Damania, R., Nash, J. and Russ, J. (2015) Highways to Success or Byways to Waste: Estimating the Economic Benefits of Roads in Africa. World Bank Publications, Washington DC. http://hdl.handle.net/10986/22551 https://doi.org/10.1596/978-1-4648-0654-4

[15] Markus, S. and Jean-Paul, R. (2004) The Transport Geography of Logistics and Freight Distribution.

[16] Van Der Horst, M.R. and De Langen, P.W. (2008) Coordination in Hinterland 
Transport Chains: A Major Challenge for the Seaport Community. Maritime Economics \& Logistics, 10, 108-129. https://doi.org/10.1057/palgrave.mel.9100194

[17] Veenstra, A.W., Zuidwijk, R. and Van Asperen, E. (2012) The Extended Gate Concept for Container Terminals: Expanding the Notion of Dry Ports. Maritime Economics \& Logistics, 14, 14-32. https://doi.org/10.1057/mel.2011.15

[18] Foster, V. and Briceño-Garmendia, C. (2010) Africa's Infrastructure: A Time for Transformation. Agence Française de Développement \& the World Bank, Washington DC. http://hdl.handle.net/10986/2692

[19] World Bank (2013) Unlocking Africa's Agricultural Potential: An Action Agenda for Transformation. Africa Region Sustainable Development Series, World Bank, Washington DC.

[20] World Bank (2007) Evaluation of World Bank Support to Transportation Infrastructure. Internal Evaluation Group, World Bank, Washington DC.

[21] World Bank (2014) Transport: Sector Results Profile-Sustainable Transport for All: Helping People to Help Themselves. World Bank, Washington DC.

[22] Supee, T. and Gael, R. (2009) Transport Prices and Cost in Africa: A Review of the Main International Corridors.

[23] Kingsley, C. (2016) Quality of Freight Mobility and Intermodal Connectivity in Sub-Saharan Africa. International Journal of Novel Research in Humanity and Social Sciences, 3, 108-130.

[24] Infrastructure Consortium for Africa (2014) Infrastructure Financing Trends in Africa. Annual Report 2014, Author, Abidjan.

https://www.icafrica.org/fileadmin/documents/Annual_Reports/INFRASTRUCTU RE_FINANCING_TRENDS_IN_AFRICA_-_2014.pdf

[25] De Langen, P.W. (2007) Port Competition and Selection in Contestable Hinterlands; the Case of Austria. European Journal of Transport and Infrastructure Research, 7, 1-14.

[26] Coyle, J., Bardi, E. and Novack, R. (2006) Transportation, Thomson South-Western, Mason, $\mathrm{OH}$.

[27] Qu, Y., Bektaş, T. and Bennell, J. (2014) Multimode Multicommodity Network Design Model for Intermodal Freight Transportation with Transfer and Emission Costs. Networks and Spatial Economics Sustainability SI, 1-27.

[28] Berg van de, R. (2015) Strategies and New Business Modules in Intermodal Hinterland Transport. Technische Universiteit Eindhoven, Eindhoven.

[29] Banister, D. and Berechman, J. (2003) Transport Investment and Economic Development. UCL Press, London. https://doi.org/10.4324/9780203220870

[30] Sergio, O.J. and Francesc, M. (2018) Patchwork in an Interconnected World: The Challenges of Transport Networks in Sub-Saharan Africa. Transport Reviews, 38, 710-736. https://doi.org/10.1080/01441647.2017.1414899

[31] Richard, P. (2018) The Eurasian Landbridge: Linking Regional Value Chains. https://voxeu.org/article/eurasian-landbridge-linking-regional-value-chains 